\title{
Til barnets beste? Beslutningsprosessen om å avslutte livsforlengende behandling
}

\section{Marianne Mork Alnæs}

Barnesykepleier og fagutviklingssykepleier

Barne- og ungdomsklinikken, Avdeling for barnemedisin og transplantasjon, Oslo universitetssykehus

\section{Therese Lyseggen}

Barnesykepleier og koordineringssykepleier

Barne- og ungdomsklinikken, Barneavdeling for kreft- og blodsykdommer, Oslo universitetssykehus

\section{Eva Mari Vestre}

Barnesykepleier og fagutviklingssykepleier

Barne- og ungdomsklinikken, Barneavdeling for kreft- og blodsykdommer, Oslo universitetssykehus

\section{Ingrid Helen Ravn}

\section{Førsteamanuensis}

Institutt for sykepleie og helsefremmende arbeid, Oslomet - storbyuniversitetet

Kvalitativ studie 
Bakgrunn: Barnesykepleiere og leger står overfor vanskelige beslutningsprosesser i behandlingen av barn med livstruende og livsbegrensende sykdommer. Beslutningsprosessen rundt behandling og eventuell avslutning av livsforlengende behandling av alvorlig syke barn er både faglig og menneskelig utfordrende, både for helsepersonellet og familiene.

Hensikt: Hensikten med studien var å unders $\varnothing$ ke hvilke erfaringer barnesykepleiere og leger hadde med beslutningsprosessen med å avslutte livsforlengende behandling.

Metode: Vi benyttet kvalitativt design med fokusgruppeintervju som metode. Analysen ble utført etter systematisk tekstkondensering. Åtte barnesykepleiere og leger med klinisk erfaring fra barnemedisinske avdelinger deltok i studien.

Resultat: Funnene viser at beslutningsprosessen er krevende for helsepersonellet. Hovedfunnene ble delt inn i tre kodegrupper: 1) Den gode beslutningsprosessen, 2) Barnets forståelse og medbestemmelse, og 3) Med barnets beste ifokus.

Konklusjon: Å sikre kontinuitet og etablere pasientteam ble trukket frem som viktig for å få til en god beslutningsprosess. God kommunikasjon og samarbeid med familiene og helsepersonellet seg imellom var viktig for å få til gode beslutningsprosesser med barnets beste som den viktigste målsettingen. Funnene viste at barnets autonomi og medbestemmelse ofte ikke ble ivaretatt, og at barnet i liten grad ble inkludert i beslutningsprosessen. Den medisinske utviklingen har ført til at helsepersonell opplevde det som stadig mer utfordrende å skulle vurdere hva som er til barnets beste. Det er barnet som er pasienten. Derfor er det viktig at alle beslutninger om barnets behandling skal tas til det beste for barnet.

Målet med å behandle barn med livstruende eller livsbegrensende sykdommer er å bevare liv. Balansen mellom effekten og belastningen av behandlingen gjør det nødvendig å evaluere om det er etisk, faglig og juridisk forsvarlig eller tilrådelig for barnet å fortsette behandlingen (1).

Forskning (2-4) og klinisk erfaring fra barnemedisinske avdelinger tilsier at beslutningsprosessen og planlegging av behandling for alvorlig syke barn er et utfordrende, sensitivt og sårbart tema både for helsepersonellet og familiene. 
Behandlingen må vurderes etter risiko og nytte, og barnets beste må legges til grunn for valget av behandlingsnivå. Beslutningsprosessen rundt medisinsk behandling er best når pasientteamet samarbeider, og inkluderer sykepleiere, leger, foreldre og barnet $(3,5)$.

\section{Gode retningslinjer og forskning mangler}

Helsepersonell har flere etiske utfordringer når de skal ta initiativet til samtaler om beslutningsprosessen for barn med alvorlig sykdom. Noen av utfordringene gjelder usikkerhet om når og hvordan de skal ta initiativ til samtalene, manglende kunnskap om gjeldende lovverk for barnets egne rettigheter, redsel for å frata familiene håp eller $\varnothing$ delegge tillitsforholdet (6).

Det etterlyses en bedre kartlegging og utarbeidelse av gode retningslinjer for å kunne tilrettelegge for at barnet og familiene skal ha det best mulig, og at alle som er involvert i pasientens medisinske behandling tar del i beslutningsprosessen. Det mangler relevant og tilstrekkelig forskning om dette temaet (6).

Tidlige diskusjoner om beslutninger rundt behandlingen er $\varnothing$ nskelig, men det mangler gode retningslinjer som kan være til hjelp i beslutningsprosessen, og som kan bidra til konsensus mellom alle som er involvert i medisinsk behandling av og sykepleie til alvorlig syke barn $(6,7)$.

Vi fant få studier som beskriver både sykepleieres og legers erfaringer med beslutningsprosessen rundt avslutningen av livsforlengende behandling for barn. Ingen av studiene vi fant, beskriver norske forhold, og kun et fåtall beskriver barnesykepleiernes erfaringer.

For at beslutningsprosesser rundt avslutning av livsforlengende behandling skal bli bedre med hensyn til barnets beste, var det viktig å unders $\varnothing$ ke både barnesykepleiernes og legenes erfaringer. 


\section{Forskningsspørsmål}

Vi utformet følgende forskningsspørsmål:

- Hvilke erfaringer har barnesykepleiere og leger med hvilke forutsetninger som trengs for å få til en god beslutningsprosess?

- Hvordan ivaretas prinsippet om at beslutninger om barnets behandling skal tas med hensyn til barnets beste?

\section{Metode}

Studien hadde et kvalitativt beskrivende design (8). Vi gjennomførte et fokusgruppeintervju med åtte informanter fra ulike barneavdelinger for å belyse beslutningsprosesser på sykehus som berørte samarbeid mellom barnesykepleiere og leger.

Ved følsomme og tabubelagte temaer som berører flere personer, kan et fokusgruppeintervju hjelpe informantene med å uttrykke egne meninger og erfaringer (8).

\section{Utvalg}

Vi benyttet et strategisk utvalg. Barnesykepleiere og barneleger fra fem ulike barnemedisinske avdelinger på et sykehus i Helse s $\varnothing$ r- $\varnothing$ st ble kontaktet. For å innhente erfaringer med god informasjonsstyrke var det $\varnothing$ nskelig at informantene hadde minst to års erfaring fra barnemedisinske avdelinger.

Informantene måtte også ha erfaring fra vanskelige beslutningsprosesser knyttet til livsforlengende behandling av barn $(8,9)$ (se faktaboks).

\section{Begrepsavklaringer}

\section{Livstruende og livsbegrensende sykdommer}

Uhelbredelige sykdommer som med stor sannsynlighet fører til at barnet dør i løpet av barndommen eller ungdomsårene, betegnes som en livsbegrensende sykdom. Livstruende sykdom er alvorlige tilstander der medisinsk behandling kan føre til helbredelse, men der behandlingen ikke alltid gir tilstrekkelig effekt. 


\section{Beslutningsprosessen}

Med beslutningsprosess menes beslutninger om behandling og behandlingsnivå i situasjoner der barn med livstruende eller livsbegrensende sykdom ikke lenger har effekt av behandlingen som gis, eller det antas at behandlingen gir barnet mer lidelse enn nytte på både kort og lang sikt.

Kilder: Helsedirektoratet (5), McNamara-Goodger K og Feudtner C (27)

Ledelsen på de ulike avdelingene foreslo aktuelle kandidater. De som oppfylte inklusjonskriteriene, ble kontaktet via e-post med informasjon om studien og samtykkeskjema.

Totalt seksten ble forespurt. Fire barnesykepleiere og fire leger fra tre poster ble inkludert, et flertall var kvinner. Alle hadde lang klinisk erfaring fra sine poster.

\section{Datainnsamling}

Vi gjennomførte fokusgruppeintervjuet på sykehuset $\mathrm{i}$ desember 2018 over to timer. Tre av forfatterne deltok $\mathrm{i}$ intervjuet. En var moderator og ledet intervjuet, en hadde ansvaret for å sørge for at alle informantene fikk uttrykt sin mening, og den tredje noterte hovedelementer i samtalen $(8,10)$.

Intervjuet ble tatt opp på lydbånd og slettet etter ferdig analyse. De tre forfatterne som deltok i intervjuet, transkriberte teksten hver for seg. Transkriberingen resulterte i 17053 ord.

Fokusgruppeintervjuet tok utgangspunktet i en semistrukturert intervjuguide (tabell 1). Hovedtemaene var basert på tidligere forskning og klinisk erfaring. Underspørsmålene var ment å hjelpe informantene til å utdype svarene ytterligere, men ble lite brukt da informantene var flinke til å utdype svarene sine (8).

Vi gjennomførte et pilotintervju (10) for å teste innholdet og rekkefølgen på spørsmålene. På bakgrunn av dette ekskluderte vi noen spørsmål. 
Tabell 1. Intervjuguide

Tema: Tverrfaglig beslutningsprosess - Til barnets beste

Hvilke opplevelser og erfaringer har dere med beslutningsprosessen rundt avslutning av livsforlengende behandling hos barn?

1. Hvem anser dere som en del av det tverrfaglige teamet som skal inkluderes i en beslutningsprosess?

- Hvilke erfaringer har dere rundt samarbeidet?

- Hvilken betydning har tverrfaglig samarbeid for beslutningsprosessen?

- Hvem skal ta opp temaet om å avslutte behandling, og på hvilket tidspunkt?

- Hvilke vurderinger ligger bak beslutningen?

2. Dersom uenighet, hvilke vurderinger i det aktuelle tverrfaglige teamet vektlegges tyngst? Barnets, foreldrenes eller helsepersonellets?)

- Hvilke erfaringer har dere med å bruke etisk komité?

3. Hvilke etiske utfordringer erfarer dere i beslutningsprosessen?

- Hvilke rammer kan eventuelt vanskeliggjøre en optimal beslutningsprosess?

4. Hvilke positive erfaringer har dere med beslutningsprosessen?

- Hvilke rammer/forutsetninger la grunnlaget for den gode erfaringen?

Hvordan ivaretas prinsippet om at beslutninger

om barnets behandling skal tas med hensyn til barnets beste?

1. Hvilke erfaringer har dere med å skulle inkludere barnet i beslutningsprosessen?

- Hvor høyt vektlegges barnets mening dersom det har rett til å bli hørt?

- Hvis barn trekkes inn i slike beslutninger, hvordan gjør dere det?

- Hvordan vektlegges bivirkninger versus liten effekt av tidligere behandling

i beslutningsprosessen?

2. Hvilke erfaringer har dere med foreldrenes rolle i beslutningsprosessen? - Hvordan tar dere hensyn til foreldrenes synspunkter?

\section{Analysen}

\section{Datamaterialet ble analysert med}

systematisk tekstkondensering, som besto av fire trinn

(8) (figur 1). I trinn én etablerte vi et helhetsinntrykk

ved å lese teksten flere ganger, og vi utarbeidet

foreløpige temaer. I neste trinn omdannet vi

meningsbærende enheter til koder ved hjelp av

fargekoding. Temaer som dekket samme sak, ble

identifisert.

Figur 1. Systematisk tekstkondensering

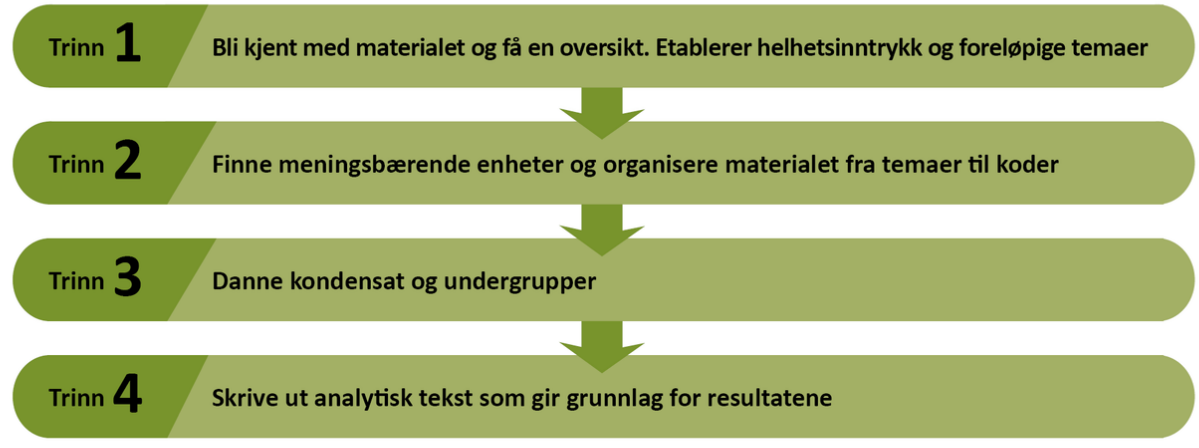

Beskrivelse av de ulike trinnene i Malteruds systematiske tekstkondensering,

som ble brukt i analyseprosessen (8). 
I trinn tre trakk vi ut essensen fra dataene som ble kodet i punkt to. Vi dannet kondensat til de ulike meningsbærende enhetene og undergrupper til de ulike kodegruppene. I det siste trinnet utarbeidet vi en analytisk tekst som dannet grunnlaget for resultatet. Tabell 2 viser et utdrag av analysen.

Tabell 2. Utdrag fra analyseprosessen

\begin{tabular}{|c|c|c|c|}
\hline $\begin{array}{l}\text { Meningsbærende } \\
\text { enhet }\end{array}$ & Kondensat & $\begin{array}{l}\text { Undergruppe } \\
\text { (kode) }\end{array}$ & $\begin{array}{l}\text { Kodegruppe } \\
\text { (hovedgruppe) }\end{array}$ \\
\hline $\begin{array}{l}\text { S1: «Vi tar oss ikke tid til dem, tør jeg å si nesten. } \\
\text { For man klarer å få det til. Hvis man virkelig vil, så } \\
\text { hadde man fått det til, tenker jeg. Hvis man jobber som } \\
\text { et team.Men en sånn refleksjon gjør jo at man tenker litt } \\
\text { nytt. Altså, man tar dette og snakker om det, så husker } \\
\text { man kanskje litt mer på det i en travel hverdag.» }\end{array}$ & $\begin{array}{l}\AA \text { ta seg tid til refleksjoner } \\
\text { ogsamtale i en travel hverdag } \\
\text { vil gjøre jobben lettere senere } \\
\text { og gjøre at man kanskje tenker } \\
\text { nytt og løsningsorientert. }\end{array}$ & Tid & $\begin{array}{l}\text { Den gode } \\
\text { beslutnings- } \\
\text { prosessen }\end{array}$ \\
\hline $\begin{array}{l}\text { L1: «Jeg tenker at da er du inne på et område der at 'ja, } \\
\text { det finnes en behandling, men det er liten sjanse, men } \\
\text { det finnes en behandling'. Da er det jo ofte sånn at ja, } \\
\text { da forsøker vi jo det. Sånn er jo medisinen blitt, at da } \\
\text { går vi jo videre på det, ikke sant, da tar vi neste skritt.» }\end{array}$ & $\begin{array}{l}\text { I dagens medisin er det } \\
\text { så mange valg at man gjerne } \\
\text { prøver én ting til selv om det er } \\
\text { liten sjanse for at behandlingen } \\
\text { vil være vellykket. }\end{array}$ & $\begin{array}{l}\text { Vurdering } \\
\text { av effekt og } \\
\text { lidelse }\end{array}$ & $\begin{array}{l}\text { Med barnets } \\
\text { beste i fokus }\end{array}$ \\
\hline
\end{tabular}

\section{Etiske og metodiske betraktninger}

Studien er godkjent av Personvernombudet for forskning ved Norsk samfunnsvitenskapelig datatjeneste (NSD), referansekode 780166, samt personvernavdelingen på det aktuelle sykehuset. Alle informantene signerte et informert samtykke.

\section{Resultater}

Analysen resulterte i tre hovedgrupper (figur 2): Den

gode beslutningsprosessen, Barnets forståelse og medbestemmelse, og Med barnets beste i fokus. 


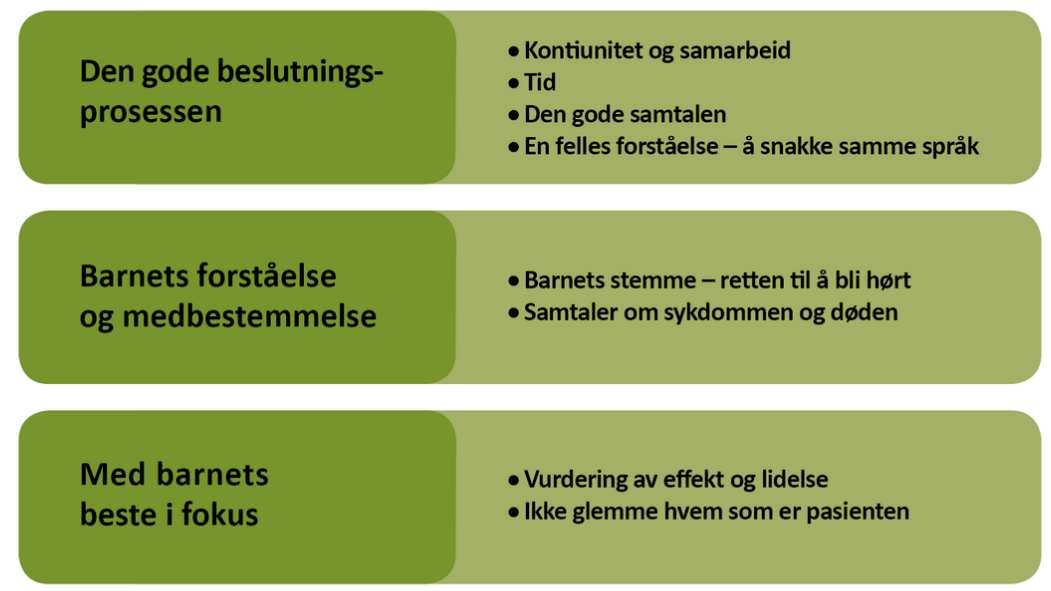

\section{Den gode beslutningsprosessen}

Flere informanter nevnte hvor viktig det var å etablere et pasientteam for å få til en god beslutningsprosess. En understreket at samarbeid og god kommunikasjon mellom leger og sykepleiere kan motvirke tverrfaglige motpoler.

En lege erfarte at sykepleierne har et mer helhetlig bilde av pasienten fordi de står tettere på familien med en større oversikt:

«Noen ganger føler jeg kanskje at sykepleierne har et litt mer helhetlig bilde av pasienten. Mens legene har litt mer sånn diagnosetilnærming, ikke alle leger og ikke alle sykepleiere, men at det er litt sånn at denne sykdommen her vil jeg at vi skal klare å lege. Ikke hele pasienten, men sykdommen» (L2).

Dårlig tid ble trukket frem av flere som en faktor som hemmer en god beslutningsprosess. Tidsmangelen giør at informantene opplevde det som utfordrende å snakke sammen innad i pasientteamet:

«Jeg tror man bør bli flinkere til å ta de fem minuttene, å snakke sammen, istedenfor at alle skylder på at man har for dårlig tid» $(\mathrm{S} 1)$. 
Informantene bemerket at dagens medisin blir mer teknisk, med høye krav til effektivitet. En barnesykepleier nevnte at lite rom for de gode samtalene kunne bli en konsekvens.

Det var enighet om at beslutningsprosessen skal være tverrfaglig, og et samarbeid mellom helsepersonellet og familien ble ansett som viktig for å få alle med på avgjørelsen. Det var uenighet om hvorvidt andre enn de som var i pasientens tverrfaglige team, kunne initiere til samtaler om pasientens tilstand.

En felles forståelse for situasjonen var nødvendig for å bestemme videre behandlingsnivå, og foreldrenes synspunkter var viktig i beslutningen om å avslutte livsforlengende behandling. Flere opplevde det som et stort etisk dilemma når det var uenighet om eller ulik forståelse av barnets situasjon.

\section{Barnets forståelse og medbestemmelse}

Informantene ønsket at barna blir involvert tidligere $\mathrm{i}$ beslutningsprosessen dersom de er i stand til det, for å $\varnothing$ ke barnets forståelse av sin egen situasjon og bidra til medbestemmelse.

Informasjon til barnet ble vektlagt som viktig, men ble ikke alltid gitt. Det var vanskelig å informere barna uten foreldrenes tillatelse, selv når de visste at barnet har rett til informasjon og medbestemmelse:

«Det er foreldrene som er barnas advokater, deres støtteapparat og står dem nærmest. Så det er jo det at når vi ikke har med dem, at man føler at det blir vanskelig å snakke direkte til barna. Man kan jo ikke trampe over det» (L1).

\section{«Informasjon til barnet ble vektlagt som viktig, men ble ikke alltid gitt.»}


Flere mente at barna ofte forstår mer enn

helsepersonellet og foreldrene tror, men at barna ikke tar initiativ til å snakke om sykdommen og døden, med mindre helsepersonellet åpner for det. Det å snakke om alvoret rundt sykdommen er sentralt for at barnet skal kunne involveres i beslutningsprosessen etter alder og modenhet:

«Jeg tror at ungene kjenner det på kroppen. De kjenner jo igjen symptomene, de kjenner at det ikke funker lenger, så jeg tror av og til både foreldre og vi er litt for redde for å gå inn i samtaler. De skjønner at vi skjønner det, de skjønner at foreldrene skjønner det, og at ingen snakker om det» (S2).

\section{Med barnets beste i fokus}

Informantene syntes det var vanskelig å vite når de skal avslutte livsforlengende behandling. Selv om barnets beste skal være styrende for beslutningsprosessen, ble det ikke alltid tatt hensyn til.

Informantene tok flere ganger opp vanskeligheten med hvor mye bivirkninger det er greit å tolerere i løpet av behandlingen. En av legene mente at allmennheten så på døden som fienden, og at samfunnet tror man har resignert hvis livsforlengende behandling avsluttes.

En barnesykepleier opplevde at lang klinisk erfaring gjorde vurderingen om å avslutte behandling utfordrende fordi de hadde erfart tilfeller der barnet overlevde selv om kurasjon tidligere ikke var mulig. Parallelt med at det i dag finnes bedre behandlingstilbud, nevnte flere at det er mer oppmerksomhet på barnets livskvalitet.

Det å huske på hvem som er pasienten, ble trukket frem av flere av informantene. En lege mente at foreldrene ofte har sterke $\varnothing$ nsker om barnets behandling, men at det ikke er de som er pasienten. 
Informantene understreket at man må lytte til foreldrene for å vurdere hva som var god livskvalitet for barnet, men at målsettingen alltid må være barnets beste.

\section{Diskusjon}

\section{Den gode beslutningsprosessen}

Samarbeid og god kommunikasjon innad i pasientteamet var viktig for en felles forståelse. Uenighet om hvorvidt de skulle avslutte behandlingen, gjorde beslutningene vanskelige. En lege mente at uenighet $\mathrm{i}$ helsepersonellgruppen skyldtes at sykepleierne kunne ha et mer helhetlig bilde av pasienten, mens enkelte leger har en mer diagnostisk tilnærming.

Barnets beste i beslutningsprosessen ivaretas ved å fokusere på barnet med sykdommen istedenfor å være opptatt av diagnosen (11). Faglige uenigheter kan også skyldes at leger og sykepleiere har ulike funksjoner. Legen har det juridiske ansvaret (5), mens barnesykepleieren står tettere på lidelsen til barnet og familien i sin barnesykepleierfunksjon (12).

\section{«Funnene tyder på at dårlig tid og lite initiativ gjør det vanskelig å få til en felles enighet.»}

En informant opplevde derimot at det ikke var noen faglige uenigheter mellom sykepleiere og leger når de tok seg tid til å snakke sammen innad i pasientteamet. Flere av informantene nevnte at det i liten grad ble tatt initiativ til tverrfaglig diskusjon, selv av dem som anså det som sitt ansvarsområde. Funnene tyder på at dårlig tid og lite initiativ gjør det vanskelig å få til en felles enighet.

Når informantene diskuterte samarbeidet mellom helsepersonellet og foreldrene, var etablering av pasientteam, kontinuitet og god kommunikasjon viktig for å få til en god beslutningsprosess. Informantene erfarte at det var vanskelig å ivareta kontinuitet på grunn av andre arbeidsoppgaver. 
Funnene st $\varnothing$ ttes av tidligere forskning $(13,14)$, som viser til at foreldrene opplevde at for mange sykepleiere og leger var involverte i pleien, og at et tidlig etablert tillitsforhold og kontinuitet er viktige faktorer som bidrar til gode beslutningsprosesser.

Informantene fortalte at det var viktig å snakke med barn og foreldre for å skape en felles forståelse. God kommunikasjon kan forebygge uenighet mellom helsepersonellet og foreldrene og bidra til at foreldrene føler seg sett, hørt og lyttet til. Det å sette seg ned og unngå forstyrrende elementer tilrettelegger mer for den gode samtalen.

Prosedyrer og tidsmangel hemmer god kommunikasjon og individuelle tilpasninger, noe som samsvarer med tidligere forskning (13, 14). Mangel på god kommunikasjon mellom familier og helsepersonell kan forstyrre familienes evne til å ta beslutninger om videre behandling av barnet, og får konsekvenser for beslutningsprosessen (15).

Informantene opplevde at det var vanskelig å ta beslutningen om å avslutte livsforlengende behandling hvis ikke foreldrene og eventuelt barnet godtok denne avgjørelsen. Helsepersonell tar beslutningen om å avslutte eller fortsette behandling uten å involvere foreldrene for å beskytte dem (16).

\section{«Informantene vektla i stor grad foreldrenes synspunkt.»}

$\AA$ ikke inkludere foreldrene avviker fra våre funn, der informantene i stor grad vektla foreldrenes synspunkt. Det kan oppstå uenighet om hvem som har autoritet til å ta den endelige beslutningen (15), selv om det er ansvarlig lege som har det juridiske og medisinske ansvaret $(2,5)$. 
Foreldre er mer delaktig i beslutningsprosessen dersom de får tid til å reflektere over hva som er til barnets beste $(14,17)$. Som en del av det å skape en felles forståelse er helsepersonell etter lovverket pliktig til å gi informasjon til pasienten og de pårørende og sikre at informasjonen er forstått (18, 19).

I vår studie adresserte informantene en faglig og etisk utfordring rundt uenighet om hvem som hadde ansvaret for å snakke med familiene om å avslutte livsforlengende behandling. Denne uenigheten gjør at det tar lengre tid før helsepersonell snakker med familien, noe som kan forlenge barnets lidelse.

Funnene understreker betydningen av at helsepersonell tar initiativ til samtaler. Foreldrene opplevde at det var avgiørende for beslutningsprosessen at helsepersonell er åpne om sensitive og sårbare temaer $(13,14)$.

\section{Barnets forståelse og medbestemmelse}

Barnet bør inkluderes i beslutningsprosessen der det er mulig etter alder og modenhet, og bli hørt i avgjørelser som angår dem selv. Så langt det lar seg gjøre, skal helsehjelpen avgjøres i et samarbeid med barnet gjennom informert samtykke (20).

Inkluderingen kan gi barnet større innsikt i og forståelse for egen sykdom og behandlingsforløp (1, 21). Flere av informantene opplevde at barnets autonomi og medbestemmelse var fraværende i beslutningsprosessen, og at barna i liten grad ble inkludert, informert og lyttet til.

\section{«Flere av informantene opplevde at barnets autonomi og medbestemmelse var fraværende i beslutningsprosessen.»}


Informantene syntes det var vanskelig å inkludere barnet uten foreldrenes tillatelse. Foreldre kan ikke nekte barnet informasjon, men kan påvirke hvordan informasjonen blir gitt. Det er ingen nedre aldersgrense som avgjør hvorvidt barnet har rett til å bli hørt, og informasjonen som blir gitt, skal være tilpasset alder og modenhet (18).

Denne problemstillingen plasserer helsepersonell i et etisk dilemma. På den ene siden har barnet rett til informasjon fra helsepersonellet (19), mens på den andre siden er helsepersonellet redde for å miste foreldrenes tillit. Informantene påpekte viktigheten av å inkludere foreldrene, som er barnas st $\varnothing t t e a p p a r a t ~ o g$ står dem nærmest, men erfarte det som etisk utfordrende når foreldrene ikke ønsket at barna skulle informeres.

Flere fortalte at redsel for å bryte foreldrenes tillit ble prioritert over barnets rettigheter og behov. Funnene i studien vår antyder at helsepersonell vektlegger foreldrenes mening over lovverket. Det foreldrene anser som barnets beste, avgjør om barnet får informasjon eller ikke.

\section{Med barnets beste i fokus}

Balansen mellom effekt og byrde av behandlingen må vurderes i et etisk, faglig og juridisk perspektiv (1). Forskning (14) viser til at barn blir overbehandlet, og at de etiske situasjonene er utfordrende for helsepersonellet. Disse momentene samsvarer med funn i studien vår.

Flere av informantene erfarte at det snakkes mer om livskvalitet nå enn tidligere. Barnets beste skal være styrende for all helsehjelp $(1,22)$, men kan oppfattes ulikt av helsepersonell og familien. Barnet må ikke ta skade av behandlingen, og beslutningen som tas, må vurderes å være til barnets beste $(5,23)$. 
Informantene presiserte at det er barnet som er pasienten, og ikke foreldrene. Erfaring fra praksis og funn i studien viser at foreldrene oftere blir hørt i beslutningsprosessen enn barna. Informantene mente at både barnet og foreldrene må lyttes til, men at barnets beste skal være viktigst.

Foreldrenes naturlige ønske om at barnet skal overleve, kan overskygge lidelsen behandlingen potensielt kan påføre barnet. En informant satte spørsmålstegn ved hva som er god livskvalitet for barnet, og hvorvidt foreldrene ville valgt dette livet for seg selv.

Både erfaring samt fag- og forskningslitteratur $(5,24$, 25) viser at foreldre i noen tilfeller fors $\varnothing$ ker å kreve at helsepersonellet skal gi livsforlengende behandling. Ifølge lovverket skal helsepersonell bare gi behandling som anses som faglig og etisk forsvarlig $(19,26)$.

\section{Metodediskusjon}

Det er ingen regel om hvor mange fokusgrupper man trenger i en studie. Ett enkelt gruppeintervju kan føre til et rikt materiale med en forsvarlig informasjonsstyrke ved optimale forhold (8).

Dynamikken og diskusjonsflyten i fokusgruppen var god, noe informantene påpekte i etterkant. Derfor vurderte vi det som riktig med ett fokusgruppeintervju med hensyn til studiens omfang, selv om flere intervjuer kunne gitt et rikere datamateriale.

For å vurdere informasjonsstyrken må man se på om hvorvidt dataene har blitt utfordret underveis i samtalen (8). Vi opplevde at samhandlingen og diskusjonen i gruppen var god og førte til et rikt datamateriale som belyste ulike synspunkter på temaene.

Vi har erfaring med beslutningsprosesser. Nærheten til praksisfeltet kan påvirke studiens validitet. Faguttrykk og erfaringene informantene refererer til, er forståelige, som kan gi bedre flyt i intervjuet. 
Egne erfaringer og refleksjoner kan derimot ha hatt innvirkning på hvordan vi analyserte og tolket resultatene (10). Vi opplevde at vi klarte å ivareta forskerrollen ved at vi ikke lot egne erfaringer påvirke prosessen.

Vår erfaring som barnesykepleiere tilsa at det var store forskjeller på hva leger og barnesykepleiere vektla i prosessen. Vi antok at det ville være naturlig å skille profesjonene i større grad i presentasjonen av resultatet og i diskusjonen. Det var derfor interessant at informantene vektla mange av de samme elementene og hadde god innsikt $\mathrm{i}$ både sin egen og den andre profesjonens rolle og funksjon.

Kjønnsperspektivet ble problematisert og vurdert til ikke å ha betydning for det endelige resultatet.

Formålet med studien bygger på erfaringer, og kjønn var derfor ikke sentralt i den strategiske utvelgelsen. En homogen gruppe kan gi mindre nyansert kunnskap, men informasjonsstyrken i studien bygger på erfaringer og kompetansen blant informantene (8).

Studiens analysemetode med systematisk tekstkondensering følger en fenomenologisk oppfatning av at subjektive erfaringer er gyldig kunnskap, og at analysen beskriver relevante sider av et fenomen på en så nøyaktig måte som mulig (8).

\section{Konklusjon}

Funnene viser at informantene har erfart at de har kunnskap og $\varnothing$ nsker om hvordan beslutningsprosessen burde utføres for å ivareta barnets beste, men at det er vanskelig å gjennomføre i praksis. Barnets stemme står i fare for ikke å bli hørt. Dermed risikerer man at barnet blir lite inkludert i beslutningsprosessen. For å ivareta prinsippet om at alle beslutninger skal tas med hensyn til barnets beste, må man huske hvem som er pasienten.

Det er behov for å få mer kunnskap om beslutningsprosessen fra barnets ståsted, og hvilke konsekvenser det får for barnet ikke å bli inkludert. 
Studien bidrar til å sette en etisk aktuell og viktig problemstilling på dagsordenen. Resultatene anses å kunne benyttes i arbeidshverdagen for helsepersonell som jobber med alvorlig syke barn.

\section{Referanser}

1. Weise KL, Okun AL, Carter BS, Christian CW. Guidance on forgoing life-sustaining medical treatment. American Academy of Pediatrics. 2017;140(3):1-9.

2. Hauer J. Pediatric palliative care. UpToDate. 2017. Tilgjengelig fra:

https://www.uptodate.com/contents/pediatricpalliative-care (nedlastet 17.01.2018).

3. Smith A. Communication of prognosis in palliative care. UpToDate. 2017; Tilgjengelig fra: https://www.uptodate.com/contents/communicationof-prognosis-in-palliative-care?source=see_link (nedlastet 17.01.2018).

4. Dupont-Thibodeau A, Hindié J, Bourque CJ, Janvier A. Provider perspectives regarding resuscitation decisions for neonates and other vulnerable patients. The Journal of Pediatrics. 2017;188(3):142-7.

5. Helsedirektoratet. Nasjonal faglig retningslinje for palliasjon til barn og unge uavhengig av diagnose. Oslo: Helsedirektoratet; 2017. Tilgjengelig fra: https://helsedirektoratet.no/retningslinjer/palliasjontil-barn-og-unge/seksjon?Tittel=grunnleggendebarnepalliasjon-etikk-og-5715\#uenighet-ombeslutninger-om-behandling-av-barnetdr\%C3\%B8ftes-i-\%C3\%A5pen-dialog (nedlastet 23.01.2018).

6. Hein K, Knochel K, Zaimovic V, Reinmann D, Monz A, Heitkamp et al. Identifying key elements for paediatric advance care planning with parents, healthcare providers and stakeholders: a qualitative study. Palliative Medicine. 2020;34(3):300-8.

DOI: $10.1177 / 0269216319900317$ 
7. Sasazuki M, Yasunari S, Kira R, Toda N, Ichimiya Y, Akamine $\mathrm{S}$ et al. Decision-making dilemmas of paediatricians: a qualitative study in Japan. BMJ Open. 2019;9(8):e026579. DOI: 10.1136/bmjopen-2018-026579

8. Malterud K. Kvalitative metoder i medisinsk forskning: En innføring. 4. utg. Oslo:

Universitetsforlaget; 2017.

9. Johannessen A, Tufte PA, Kristoffersen L. Introduksjon til samfunnsvitenskapelig metode. 5. utg. Oslo: Abstrakt; 2016.

10. Kvale S, Brinkmann S. Det kvalitative forskningsintervju. 3. utg. Oslo: Gyldendal Akademisk; 2015 .

11. NOU 2017: 16. På liv og død. Palliasjon til alvorlig syke og døende. Oslo: Departementenes servicesenter, Informasjonsforvaltning; 2017.

12. Barnesykepleieforbundet NSF (BSF).

Barnesykepleier - funksjons- og ansvarsområder. Oslo: NSF; 2017.

13. Lotz JD, Daxter M, Jox RJ, Borasio GD, Fürer M. «Hope for the best, prepare for the worst»: a qualititive interview study on parents' needs and fears in pediatric advance care planning. Palliative Medicine. 2016;31(8):764-71. DOI:

$\underline{10.1177 / 0269216316679913}$

14. Popejoy E, Pollock K, Almack K, Manning JC, Johnston B. Decision-making and future planning for children with life-limiting conditions: a qualitative systematic review and thematic synthesis. Child: Care, Health and Development. 2017;43(5):627-44. DOI: $\underline{10.1111 / \text { cch.12461 }}$ 
15. Richards CA, Starks H, O'Connor RM, Bourget E, Hays RM, Doorenbos AZ. Physicians perceptions of shared decision-making in neonatal and pediatric critical care. American Journal of Hospice \& Palliative Medicine. 2018;35(4):669-76. DOI:

$\underline{10.1177 / 1049909117734843}$

16. De Vos MA, Bos AP, Plötz FB, Van Heerde M, De Graaff BM, Tates K et al. Talking with parents about end-of-life decisions for their children. Pediatrics. 2014;135(2):465-76. DOI: $10.1542 /$ peds.2014-1903

17. Aarthun A, Akerjordet K. Parent participation in decision-making in health-care services for children: an integrative review. Journal of Nursing Management. 2012;22(2):177-91. DOI: 10.1111/j.1365-2834.2012.01457.X

18. Lov 2. juli 1999 nr. 63 om pasient- og brukerrettigheter (pasient- og brukerrettighetsloven). Tilgjengelig fra:

https://lovdata.no/dokument/NL/lov/1999-07-02-63? q=pasient\%200g\%2obrukerrettighetsloven (nedlastet 25.01.2018).

19. Lov 2. juli 1999 nr. 64 om helsepersonell (helsepersonelloven). Tilgjengelig fra: https://lovdata.no/dokument/NL/lov/1999-07-02-64? q=helsepersonelloven (nedlastet 25.01.2018).

20. Lov 17. mai 1814. Kongeriket Noregs grunnlov (grunnlova). Tilgjengelig fra:

https://lovdata.no/dokument/NL/lov/1814-05-17-nn? q=kongeriket\%2onoregs\%2ogrunnlov (nedlastet 25.01.2018).

21. Whitty-Rogers J, Alex M, MacDonald C, Gallant DP, Austin W. Working with children in end-of-life decision making. Nursing Ethics. 2009;16(6):743-57. DOI: $10.1177 / 0969733009341910$ 
22. Larcher V, Craig F, Bhogal K, Wilkinson D, Brierley J. Making decisions to limit treatment in life-limiting and life-threatening conditions in children: a framework for practice on behalf of the Royal College of Paediatrics and Child Health. Arch Dis Child. 2015;100(2):1-26. DOI: 10.1136/archdischild-2014306666

23. Slettebø Å. Sykepleie og etikk. 6 utg. Oslo: Gyldendal Akademisk; 2013.

24. Larcher V, Carnevale F. Etikk. I: Goldman A, Hain R, Liben S, red. Grunnbok i barnepalliasjon. 1. utg. Oslo: Kommuneforlaget; 2016.

25. Fromme EK, Smith MD. Ethical issues in palliative care. UpToDate. 2017. Tilgjengelig fra:

https://www.uptodate.com/contents/ethical-issues-in$\underline{\text { palliative-care?source }=\text { see_link (nedlastet 17.01.2018). }}$

26. Lov 2. juli 1999 nr. 61 om spesialisthelsetjenesten (spesialisthelsetjenesteloven). Tilgjengelig fra: https:/lovdata.no/dokument/NL/lov/1999-07-02-61? $\underline{\mathrm{q}=\text { spesialisthelsetjenesteloven (nedlastet 25.01.2018). }}$

27. McNamara-Goodger K, Feudtner C. Historikk og epidemiologi. I: Goldman A, Hain R, Liben S, red. Grunnbok i barnepalliasjon. 1. utg. Oslo: Kommuneforlaget; 2016. 